\title{
Relative humidity during cold storage on Postharvest quality of 'Niagara Rosada' table grapes
}

\author{
Umidade relativa durante o armazenamento refrigerado sobre a qualidade pós-colheita de uvas de \\ mesa 'Niagara Rosada'
}

\author{
Josuel Alfredo Vilela Pinto ${ }^{\mathrm{I}}$ Márcio Renan Weber Schorr ${ }^{\mathrm{II}}$ Fabio Rodrigo Thewes ${ }^{\mathrm{III}}$ \\ Deiverson Luiz Ceconi ${ }^{\text {IV }}$ Vanderlei Both $^{\text {II }}$ Auri Brackmannv ${ }^{\text {Diniz Fronza }}{ }^{\text {I }}$
}

\section{ABSTRACT}

This study aimed to evaluate the effect of different levels of relative humidity $(R H)$ on the maintenance of Postharvest quality of 'Niagara Rosada' table grapes after cold storage at $0.5^{\circ} \mathrm{C}$ for 21 days. A completely randomized design was used, with five replicates of 18 clusters per treatment. The selected levels of relative humidity were $85,90,95$ and $100 \%$, obtained by means of electronic humidity controllers. The fruits were evaluated in relation to rot incidence, berry cracking, browning rate, respiratory rate, titratable acidity, soluble solids, resistance to abscission, berry drop and weight loss. The evaluations were assessed at 20 days of storage and after two and four days of shelf-life $\left(20^{\circ} \mathrm{C}\right.$; $85 \% \mathrm{RH})$. The results showed that as higher as relative humidity, higher is rot incidence and that the variables rachis browning and weight loss were inversely related to relative humidity. Resistance to abscission at the end of storage was higher when humidity ranged between 90 and 95\%, but it was not affected after transfer to shelf-life from cold storage. Relative humidity ranging between 90 and 95\% offer the best conditions to maintain the Postharvest quality of 'Niagara Rosada' table grapes.

Key words: Vitis labrusca, table grapes, physiological disorders, weight loss.

\section{RESUMO}

Este trabalho teve como objetivo avaliar o efeito de diferentes niveis de umidade relativa (UR) sobre a manutenção da qualidade pós-colheita de uvas de mesa 'Niagara Rosada', após armazenamento sob refrigeração, a $0,5^{\circ} \mathrm{C}$ durante 21 dias. Foi utilizado delineamento inteiramente casualizado, com cinco repetições de 18 cachos por tratamento. Os niveis de umidade relativa utilizados foram 85, 90, 95 e 100\%, conseguidos com o auxilio de controladores eletrônicos. Os frutos foram avaliados quanto à incidência de podridões e rachaduras, indice de escurecimento, taxa respiratória, acidez titulável, sólidos solúveis, resistência ao degrane, degrane e perda de massa. As avaliações foram realizadas aos 20 dias de armazenamento e após dois e quatro dias de exposição dos frutos à condição ambiente $\left(20^{\circ} \mathrm{C}\right.$; $85 \%$ UR). Os resultados indicaram que quanto maior o teor de umidade, maior a incidência de podridões, e que as variáveis escurecimento da ráquis e perda de massa possuem relação inversa à umidade relativa. A resistência ao degrane na saída da câmara foi maior com umidade entre 90 e 95\%, mas não foi afetada após a transferência dos cachos à condição ambiente. $O$ armazenamento sob refrigeração e umidade relativa na faixa de 90 a $95 \%$ proporciona melhor manutenção da qualidade pós-colheita de uvas 'Niagara Rosada'.

Palavras-chave: Vitis labrusca, uvas de mesa, desordens fisiológicas, perda de massa.

\section{INTRODUCTION}

Grapes are one of the main fruits grown in temperate climate in Brazil, and approximately 1.3 million tones are produced annually (FAO, 2009), with the state of Rio Grande do Sul being the major producer. However, in the case of table grapes, the state of São Paulo has gained prominence, where

'Universidade Federal da Fronteira Sul (UFFS), BR-158, Km 405, 85301-970, Laranjeiras do Sul, PR, Brasil. E-mail: josuel_vilela@hotmail.com. Corresponding author.

IUniversidade Federal de Santa Maria (UFSM), Santa Maria, RS, Brasil.

IIIPrograma de Pós-graduação em Agronomia, UFSM, Santa Maria, RS, Brasil.

${ }^{\text {IV }}$ Curso de graduação em Agronomia, UFSM, Santa Maria, RS, Brasil.

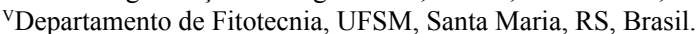

${ }^{\mathrm{VI} C}$ Colégio Politécnico, UFSM, Santa Maria, RS, Brasil. 
'Niagara Rosada' grapes, in particular, are grown (CIA et al., 2011; WUTKE et al., 2011).

'Niagara Rosada' is an american table grape, with seed, being much appreciated for fresh consumption. It is harvested at some seasons of the year, where periods of high marketable yields are followed by periods of low yields. In addition, there is increased demand from the consumer market for quality fruit, generating the need to improve the storage techniques in order to keep such quality and provide longer periods of market supply between fruit production peaks.

Cold storage, where only temperature and relative humidity are controlled in the storage chamber, is one of the main methods for conservation of fruit quality (CHITARRA \& CHITARRA, 2005; BRACKMANN et al., 2010). Thus, the reduction of temperature, up to a certain limit, increases the quality maintenance and extends the period of fruit supply to the consumer market. For grapes, the choice of storage temperature depends on the cultivar used, but the most commonly used is around $0^{\circ} \mathrm{C}$ (BRACKMANN et al., 2000). As for relative humidity, most of studies focus on storage at either high or low relative humidity and do not consider intermediate levels.

Relative humidity levels near saturation $(100 \%)$ can increase the rot incidence (SCHWARZ, 1994) and berry cracking. When it is very low, can cause excessive weight loss (BRACKMANN et al., 2000) and emergence of disorders such as rachis browning (CRISOSTO et al., 2001) and berry drop (BRACKMANN et al., 2000). Moreover, the water loss by the fruit during storage can modify the respiratory rate, the ethylene production, the juiciness and the accumulation of acids and soluble solids (BRACKMANN et al., 2007; PINTO et al., 2012).

In this context, this study aimed to evaluate the effect of different levels of relative humidity during cold storage on the Postharvest quality of 'Niagara Rosada' table grapes.

\section{MATERIAL AND METHODS}

This study was conducted at the Postharvest Research Center (NPP - Núcleo de Pesquisa em Póscolheita) from the Federal University of Santa Maria (UFSM) with 'Niagara Rosada' table grapes grown in an experimental orchard at the Polytechnic School of UFSM in the 2010/2011 agricultural year.

The grapes were grown under a trellis system, and the cultivation was performed according to local technical recommendations. The harvest was performed when the fruit reached the average content of soluble solids of $15^{\circ}$ Brix. After harvesting, the material was taken to NPP where were selected according to size (approximately 200g) and the absence of mechanical injury and pathogens. The samples were placed in experimental mini-chambers $\left(0.233 \mathrm{~m}^{3}\right)$ located inside a cold chamber.

The experiment had a completely randomized design, with five replicates of 18 clusters per treatment. Four conditions of relative humidity $(85,90,95$ and $100 \%)$ were tested during the cold storage at $0.5^{\circ} \mathrm{C}$ for three weeks. Relative humidity was kept constant by means of electronic humidity controllers that brought into action a system whereby the air in the mini-chambers circulated within a container filled with silica gel, which absorbed air humidity; already when humidity was very low, water was manually injected into the mini-chambers. The temperature and relative humidity were monitored with daily readings shown by thermometers and psychrometers, respectively, installed inside the mini-chambers.

After the storage, fruits were transferred from the cold chamber and maintained at environmental condition $\left(20^{\circ} \mathrm{C} ; 85 \% \mathrm{RH}\right)$ for four days, being evaluated every two days. The following variables were assessed: [1] Rot incidence: determined by the ratio between the number of clusters that had some type of fungal infection and the total number of clusters, with the results expressed in percentage (\%); [2] Incidence of berry cracking: determined by the ratio between clusters with cracked berries and the total number of clusters, with the results expressed in percentage (\%); [3] Rachis browning: determined subjectively by using the following scale: $0=$ no browning, $1=$ moderate browning $(<50 \%$ rachis browning) and $2=$ severe browning ( $>50 \%$ rachis browning), calculated by the weighted average of the scale value and number of clusters at each level, ranging between 0 and 2; [4] Respiratory rate: quantified according to the procedure described by PINTO et al. (2012) and the results were expressed $\mathrm{mLCO}_{2} \mathrm{~kg}^{-1} \mathrm{~h}^{-1}$; [5] Titratable acidity: measured by titration of $10 \mathrm{~mL}$ of grape juice, diluted with $100 \mathrm{~mL}$ of distilled and deionized water, with $0.1 \mathrm{~N} \mathrm{NaOH}$ until $\mathrm{pH} 8.1$, with results expressed in meq $100 \mathrm{~mL}^{-1}$; [6] Soluble solids (SS): determined with a refractometer (Biobrix 103), being the results expressed in ${ }^{\circ}$ Brix; [7] Resistance to abscission, determined by the average force required to detach 20 berries from their respective clusters, measured with a precision scale (Marconi AL500C), with the results expressed in gram-force (gf); [8] Abscission, 
determined by the ratio between the mass of berries detached after three slight manual agitations, and the total berry mass, expressed in percentage (\%); [9] Weight loss, determined by the ratio between total fruit mass measured before and after storage, being the results expressed in percentage (\%).

The statistical analysis was processed in SISVAR software, being the averages submitted to analysis of variance (ANOVA) at 5\% significance level, and the variables that were significant in the F-test submitted to regression analysis. The data expressed as percentage were submitted to arc sine transformation prior to ANOVA.

\section{RESULTS AND DISCUSSION}

Rot incidence, after 21 days of cold storage, was only observed after two days at shelf-life (temperature $20^{\circ} \mathrm{C}$; $\mathrm{RH} 85 \%$ ), and showed second degree response and point of minimum incidence with $92.9 \%$ of relative humidity (Figure $1 \mathrm{~A}$ ). There was no rot incidence in clusters removed from the cold chamber and maintained at $20^{\circ} \mathrm{C}$ for 4 days. Infection by fungus Botrytis cinerea, which is the main cause of bunch rot of table grapes (CELIK et al., 2009), usually starts in the field and remains dormant until begin fruit senescence (SANZANI et al., 2012). The onset of symptoms occurs, because of the reduced synthesis of phenolic compounds and epidermal softening (PEZET et al., 2003). This explain the fact that, in our study, there were no rot berries at removal from the cold storage chamber, but the symptoms were observed after two days at $20^{\circ} \mathrm{C}$. Furthermore, when the fruits were taken out of the cold chamber and exposed to room temperature, water condensation was observed on the surface of the berries. The reduced incidence with advancing days of storage at ambient condition was due to the detachment of rot berries from the clusters.

The incidence of berry cracking, after the transference of fruits from the cold chamber ( 0 days

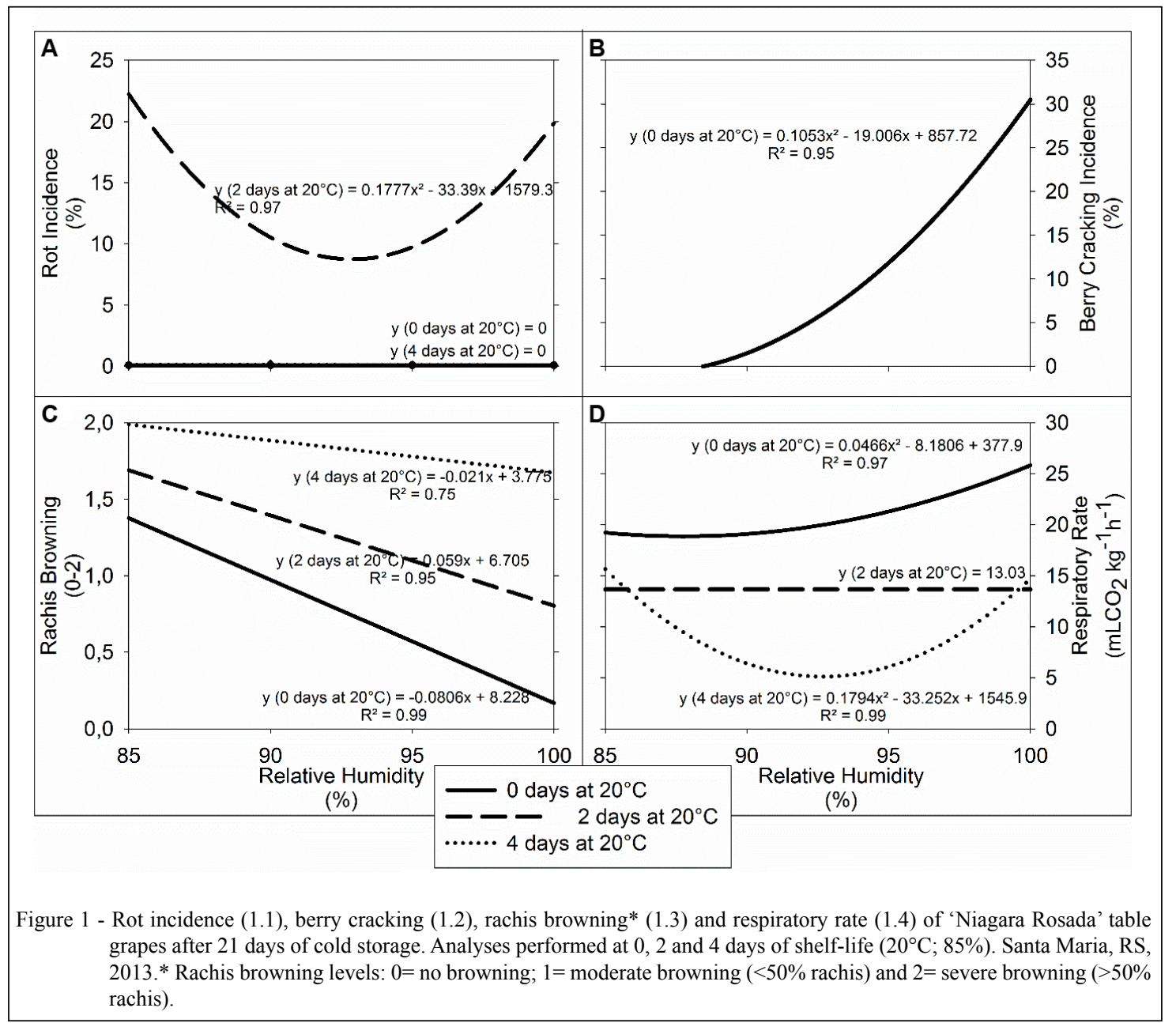

Ciência Rural, v.45, n.3, mar, 2015. 
at $20^{\circ} \mathrm{C}$ ), was directly related to relative humidity during storage and was only noticed when it was equal to or above $95 \%$, which corroborates the findings by SCHWARZ (1994) (Figure 1B). However, the rachis browning had the opposite response, i.e., increased with the reduction of the relative humidity during storage, in all days assessed (Figure 1C). Moreover, by removing the berries from the cold chamber, the browning of fruits stored at 85 and $90 \%$ relative humidity ranged between moderate and severe, which reduces the consumer acceptance of the fruits. This is in line with the findings by CRISOSTO et al. (2001), who studied the effect of water loss of berries in the occurrence of rachis browning, and those by BRACKMANN et al. (2000) in 'Dona Zila' and 'Tardia de Caxias' table grapes. The use of higher relative humidity is allowed for longer shelf-life, without excessive rachis browning.

The respiratory rate was affected by relative humidity only at 0 and 4 days of shelf-life, with the point of lowest respiration in relative humidity levels of 87.8 and $92.7 \%$, respectively (Figure 1D). After 2 days of shelf-life, the relative humidity did not change the respiratory rate significantly, and the average of the treatments was $13.67 \mathrm{mLCO}_{2} \mathrm{~kg}^{-1} \mathrm{~h}^{-1}$. As well as the respiratory rate, a difference was observed for the contents of soluble solids (SS) only at 0 and 4 days of shelf-life (Figure 2B). At 0 day, the curve that explains the effect of relative humidity was a parabola, with the maximum tenors at $94.9 \% \mathrm{RH}$, which indicates a slighter loss of SS during the storage, as a result of respiration. The titratable acidity was not significantly affected by the levels of relative humidity studied (Figure 2A).

The effect of relative humidity on resistance to abscission, which is a way to estimate the force with which the berries are attached to the rachis, was only affected at 0 days of shelf life (Figure 2C), whose response was represented by a parabola with maximum force at $92 \%$ relative

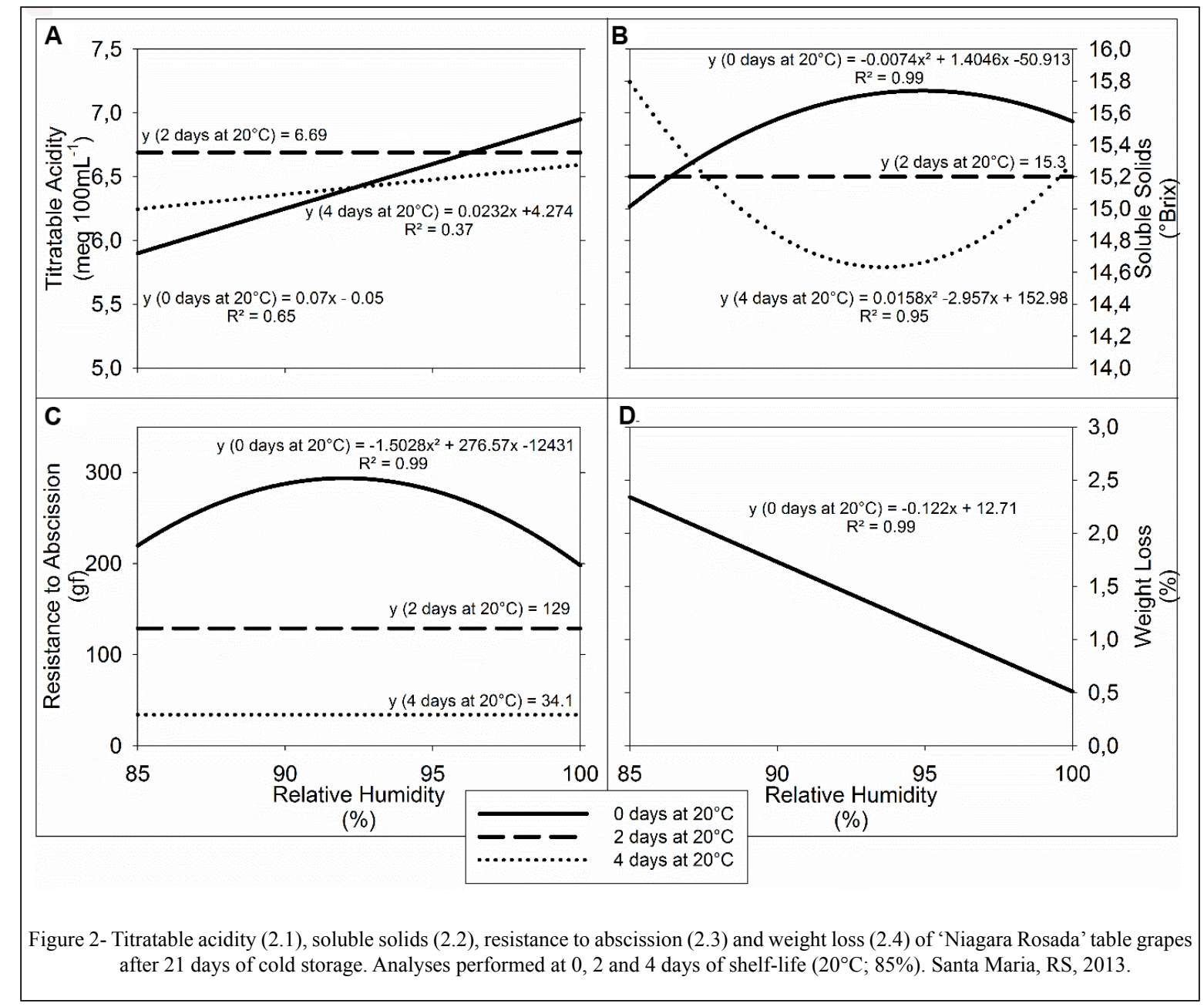

Ciência Rural, v.45, n.3, mar, 2015. 
humidity. The easiness to berries drop from the cluster is associated with the development of the abscission layer (DENG et al., 2007b) between the peduncle and the berry, a process mediated by the abscisic acid, which stimulates the activity of enzymes which degrade the cell wall (ZHANG \& ZHANG, 2009).

Indirectly correlated with resistance to abscission, berry drop was not significantly affected by relative humidity during storage; which was on average of $33.5 \%$ after 4 days at $20^{\circ} \mathrm{C}$ (data not shown). As the resistance to abscission, this variable was also directly associated with the development of the abscission layer (DENG et al., 2007b) and represents one of the main ways whereby Postharvest quality of table grapes is lost (DENG et al., 2007a; BRACKMANN et al., 2000). In its turn, the weight loss of berries during the storage was inversely related to the relative humidity, i.e., as lower levels of relative humidity, greater the weight loss, which corroborates the findings by BRACKMANN et al. (2012) (Figure $2 \mathrm{D})$. For each reduced percentage point in relative humidity, there was an average increase of 0.12 percentage points in weight loss.

\section{CONCLUSION}

'Niagara Rosada' table grapes should be kept under cold storage with relative humidity ranging between 90 and $95 \%$, because it results in lower rot incidence, lower respiration, and greater resistance to abscission, during shelf-life. Relative humidity levels equal or higher than $95 \%$ causes berry cracking.

The weight loss and rachis browning are the two major reasons for loss of Postharvest table grapes quality and are intensified with the reduction in the relative humidity, especially if it is equal or lower than $90 \%$.

The resistance to abscission and berry drop are not influenced by relative humidity during the cold storage but is severely reduced during exposition to $20^{\circ} \mathrm{C}$. In contrast, rachis browning is increased with the reduction of relative humidity.

\section{REFERENCES}

BRACKMANN, A. et al. Tolerância de maçãs 'Gala' a baixas temperaturas durante o armazenamento. Ciência Rural, v.40, n.9, p.1909-1915, 2010. Available from: <http://www.scielo.br/scielo. php?script $=$ sci_arttext\&pid=S0103-84782010000900009\&lng $=$ pt\&nrm=iso $>$. Accessed: Sept. 29, 2012. doi: 10.1590/S010384782010000900009
BRACKMANN, A. et al. Armazenamento refrigerado de uvas cvs. Tardia de Caxias e Dona Zilá. Ciência Rural, v.30, n.4, p.581-586, 2000. Available from: <http://www.scielo.br/scielo. php? script $=$ sci arttext\&pid=S0103-84782000000400004\&lng= pt\&nrm=iso\&tlng=pt $>$.Accessed: Sept. 29, 2012. doi: 10.1590/ S0103-84782000000400004.

BRACKMANN, A. et al. Indução da perda de massa fresca e ocorrência de distúrbios fisiológicos em maçãs 'Royal Gala' durante o armazenamento em atmosfera controlada. Revista Brasileira de Armazenamento, v.32, n.2, p.87-92, 2007.

CELIK, M. et al. Quantitative and qualitative analysis of Botrytis inoculated on table grapes by qPCR and antibodies. Postharvest Biology and Technology, v.52, p.235-239, 2009. Available from: $<$ http://www.sciencedirect.com/science/article/pii/ S092552140800286X>. Accessed: Sept. 29, 2012. doi: 10.1016/j. postharvbio.2008.10.007.

CIA, P. et al. Atmosfera modificada e refrigeração para conservação pós-colheita de uva 'Niagara Rosada'. Pesquisa Agropecuária Brasileira, v.45, n.10, p.1058-1065, 2010. Available from: <http://www.scielo.br/scielo.php?script=sci arttext\&pid=S0100-204X2010001000002\&lng=pt\&nrm $=$ is o\&tlng=pt $>$. Accessed: Sept. 29, 2012. doi: 10.1590/S0100204X2010001000002.

CHITARRA, M.I.F.; CHITARRA, A.B. Pós-colheita de frutos e hortaliças: fisiologia e manuseio. 2.ed. Lavras: UFLA, 2005. 785p.

CRISOSTO, C.H. et al. Table grapes suffer water loss, stem browning during cooling delays. California Agriculture, v.55, n.1, p.39-42, 2001. Available from: <http://ucce.ucdavis.edu/files/ repositoryfiles/ca5501p39-68881.pdf>. Accessed: Aug. 17, 2012. doi: 10.3733/ca.v055n01p39.

DENG, Y. et al. A mathematical model for predicting grape berry drop during storage. Journal of Food Engineering, v.78, n.2, p.500-511, 2007a. Available from: <http://www.sciencedirect. com/science/article/pii/S0260877405007235>. Accessed: Sept. 29, 2012. doi: 10.1016/j.jfoodeng.2005.10.027.

DENG, Y. et al. Effects of high $\mathrm{CO}_{2}$ and low $\mathrm{O}_{2}$ atmospheres on the berry drop of 'Kyoho' grapes. Food Chemistry, v.100, p.768-773, 2007b. Available from: <http://www.sciencedirect.com/science/ article/pii/S030881460500943X>. Accessed: Sept. 29, 2012. doi:10.1016/j.foodchem.2005.10.036.

FAO. Food and Agricultural commodities production. Available from: <http://faostat.fao.org/site/339/default.aspx> $>$. Accessed: Mar. $15,2012$.

PEZET, R. et al. Latency of Botrytis cinerea Pers.: Fr. and biochemical studies during growth and ripening of two grape berry cultivars, respectively susceptible and resistant to grey mould. Journal of Phytopathology, v.151, n.4, p.208-214, 2003. Available from: <http://onlinelibrary.wiley.com/doi/10.1046/ j.1439-0434.2003.00707.x/pdf>. Accessed: Sept. 29, 2012. doi: 10.1046/j.1439-0434.2003.00707.x.

PINTO, J.A.V. et al. Indução da perda de massa na qualidade pós-colheita de pêssegos 'Eragil' em armazenamento refrigerado. Ciência Rural, v.42, n.6, p.962-968, 2012. Available from: $<$ http://www.scielo.br/scielo.php?script=sci_arttext\&pid=S0103$84782012000600002 \& \operatorname{lng}=$ pt\&nrm $=$ iso $\&$ tlng $=$ pt $>$. Accessed: Sept. 29, 2012. doi: 10.1590/S0103-84782012000600002. 
SANZANI, S.M. et al. Early detection of Botrytis cinerea latent infections as a tool to improve postharvest quality of table grapes. Postharvest Biology and Technology, v.68, p.64-71, 2012. Available from: $<$ http://www.sciencedirect.com/science/article/pii/ S0925521412000415>. Accessed: Sept. 29, 2012. doi: 10.1016/j. postharvbio.2012.02.003.

SCHWARZ, A. Relative humidity in cool store: measurement control and influence of discreet factors. Acta Horticulturae, n.368, p.687-692, 1994.

WUTKE, E.B. et al. Produtividade da videira 'Niágara Rosada' em cultivo intercalar com adubos verdes. Revista
Brasileira de Fruticultura, v.33, n.spec., p.528-535, 2011. Available from: <http://www.scielo.br/scielo. php?script=sci_arttext\&pid=S0100-29452011000500071\&lng $=$ pt\&nrm=iso $>$. Accessed: Jul.13, 2012 doi: 10.1590/S010029452011000500071

ZHANG, Y.; ZHANG, R. Effects of ABA content on the development of abscission zone and berry falling after harvesting of grapes. Agricultural Sciences in China, v.8, n.1, p.59-67, 2009. Available from: $<$ http://www.sciencedirect.com/science/article/pii/ S1671292709600092>. Accessed: Sept. 29, 2012. doi: 10.1016/S1671-2927(09)60009-2. 